\title{
QSAR STUDIES AND ANTIMICROBIAL POTENTIAL OF 1,3-THIAZOLYLPHOSPHONIUM SALTS
}

\author{
M. M. TRUSH ${ }^{\prime *}$, V. V. KOVALISHYN ${ }^{1}$, V. M. BLAGODATNYI ${ }^{2}$, V. S. BROVARETS \\ S. G. PILYO', V. M. PROKOPENKO', D. M. HODYNA ${ }^{1}$, L. O. METELYTSIA ${ }^{1}$ \\ ${ }^{1}$ Institute of Bioorganic Chemistry and Petrochemistry, National Academy \\ of Sciences of Ukraine, Kyiv; \\ ${ }^{2}$ Shupyk National Medical Academy of Postgraduate Education, Kyiv, Ukraine; \\ *e-mail:maria@bpci.kiev.ua
}

The regression QSAR models were built to predict the antimicrobial activity of new thiazole derivatives. Compounds with high predicting activity were synthesized and evaluated against Gram-positive and Gramnegative bacteria and fungi. 1,3-Thiazole-4-ylphosphonium salts 4 and 5 displayed good antibacterial properties and high antifungal activity. The predictions are in a good agreement with the experiment results, which indicate the good predictive power of the created QSAR models.

Key words: QSAR, thiazolylphosphonium salts, antimicrobial activity.

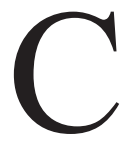

urrently, thousands of compounds with antimicrobial and biocidal activity are known but only some of them can be used to produce medicines, antiseptics and disinfectants. The need for new antimicrobials is caused by various factors: the expansion of modern antimicrobial spectrum, increasing numbers of drug-resistant microbes, improvement of pharmacological properties, toxicity reduction and others.

Thiazoles and their derivatives possess a wide range of biological activity. As a platform for drug development they can be successfully used for the treatment of allergies [1, 2], hypertension [3], inflammation [4, 5], schizophrenia [6], hypnotics [7], analgesia [8-10], HIV infections [11-13] and cancer [14-19].

Furthermore, thiazole derivatives are of considerable interest for the treatment of bacterial and fungal infections. Some of them showed good antibacterial activity against various Gram-positive (Staphylococcus aureus, Bacillus subtilis, etc.) and Gram-negative bacteria (Escherichia coli, Pseudomonas aeruginosa, etc.) [20-23], and fungi (Candida albicans, Candida glabrata, Aspergillus fumigatus) [20-25]. It is known that the thiazoles are present in a number of drugs such as Sulfathiazol (antimicrobial drug), Ritonavir (antiretroviral drug), Abafungin (antifungal drug) with trade name Abasol cream and Bleomycine and Tiazofurin (antineoplastic drugs) and others [26].
In the present paper, we propose the effective QSAR models to identify antimicrobial activity of a series of thiazole derivatives and experimental studies of selected compounds for their antibacterial and antifungal activity.

\section{Materials and Methods}

Data set. The data set consisted of 3663 thiazole derivatives as antimicrobial inhibitors were formed using ChEMBL database [27]. The range of MIC (minimum inhibitory concentration) values was from 0.1 to $15580 \mu \mathrm{g} / \mathrm{ml}$.

This set was analyzed for similarity search to test compounds by the sample under the structural search of similar chemical structures (Index SubStructure) [28] using the program Instant JChem [29]. As a result 455 compounds with the index over 0.6 were selected to build predictive QSAR models.

OCHEM. The QSAR study was performed using Online Chemical Modeling Environment (OCHEM) [30]. This web-based platform includes all the necessary steps required to build a computational model: data preparation, calculation and filtering of molecular descriptors, application of machine learning methods and analysis of a models' performance [31].

Experimental data were formed according to certain criteria: a compound represented as a SMILES string, a property, unit of measurement, a target, a source of data (publication) saved in Excel 
format and uploaded to OCHEM to create the study sample.

Machine Learning Methods. For this study, several machine-learning methods were used to build QSPR models:

An associative neural network (ASNN). This method is a combination of an ensemble of the feedforward neural networks and the k-nearest neighbor technique. The introduced network uses correlation between ensemble responses as a measure of distance amid the analyzed cases for the nearest neighbor technique and provides an improved prediction by the bias correction of the neural network ensemble $[31,32]$.

k-Nearest Neighbors (kNN). This method predicts the property using the average property value of those $k$ compounds from the training set that are nearest (in the descriptor space) to the target compound [30, 31].

Descriptors. Different kinds of molecular descriptors, which are available on the server OCHEM, were used to build QSAR models [30]: Adriana. Code (3D) comprises a unique combination of methods for calculating molecular descriptors on a sound geometric and physicochemical basis [33]; ALogPS descriptors (2D) predict $\log \mathrm{P}$ and the water solubility of chemicals [34]; Chemaxon descriptors (also known as calculator plugins) describe a range of physico-chemical and life-science related properties from chemical structures and are developed by ChemAxon [31]; E-State indices (2D) are separated on atom/bond type [35]; ToxAlerts (Structural Alerts) is an OCHEM-based platform for collecting and storing toxicological structural alerts from literature and for virtual screening of chemical libraries to flag potentially toxic chemicals and compounds that can cause adverse side effects [36].

Analysis of models. The OCHEM provides a variety of statistical instruments to analyze the quality and robustness of QSAR models.

The accuracy of each individual model was evaluated using the method of 5-fold cross-validation set. The predictive ability of regression models was assessed by means of the cross-validation coefficient $\mathrm{q}^{2}$; besides that, prediction performance of the methods was compared using the root mean squared error (RMSE) and the mean absolute error (MAE) [30, 31, 37, 38].

Applicability Domain. QSAR models should have a well-defined applicability domain (AD) within which reliable predictions can be made
$[39,40]$. According to the OCHEM prediction the test set compounds were outside the scope of the model. To assess the probability of predicted activities of the test compounds the Dice Index (DI) was used to defined their distance to the model, using the program Instant JChem [29] (Table 1).

According to the calculation, the compounds selected for biological testing were similar to the training set (DI similarity $\geq 0.6$ ) and their activity prediction is realistic.

Chemistry - Synthetic procedures and spectroscopic data of compounds

\section{[5-[(4-Chlorophenyl)thio]-2-(4-methylphe-} nyl)-1,3-thiazol-4-yll(triphenyl)phospho-nium iodide (compound 1). Compound 1 was synthesized following a procedure described in the literature [41]. Yellow powder, m.p. $233-234^{\circ} \mathrm{C}$. IR $\left(\mathrm{KBr}, v_{\max }\right.$, $\left.\mathrm{cm}^{-1}\right)$ : $1105,1380,1433 .{ }^{1} \mathrm{H}$ NMR $(400 \mathrm{MHz}, \mathrm{DM}-$ SO-d $\left.\mathrm{d}_{6}\right): \delta 2.35\left(\mathrm{~s}, 3 \mathrm{H}, \mathrm{CH}_{3}\right), 7.28-7.47(\mathrm{~m}, 6 \mathrm{H}, \mathrm{ArH})$, 7.70-7.93 (m, 17H, ArH). ESI-MS, m/z: 578 [M-I] ${ }^{+}$. Found, \%: C, 57.55\%; H, 3.62\%; N, 2.08\%; P, 4.29\%; S, 9.04\%. Calc. for $\mathrm{C}_{34} \mathrm{H}_{26} \mathrm{ClINPS}_{2}: \mathrm{C}, 57.84 \% ; \mathrm{H}$, $3.71 \%$; N, $1.98 \%$; P, 4.39\%; S, 9.08\%.

\section{[4-(Methoxycarbonyl)-2-(4-methylphenyl)-} 1,3-thiazol-5-yll(triphenyl)phosphonium perchlorate (compound 2). Compound 2 was synthesized following the procedure described in the literature [42]. Colorless powder, m.p. $120-121^{\circ} \mathrm{C}$. IR (KBr, $\left.v_{\max }, \mathrm{cm}^{-1}\right): 1096\left(\mathrm{ClO}_{4}\right), 1252,1439,1716(\mathrm{CO}) .{ }^{1} \mathrm{H}$ NMR $\left(500 \mathrm{MHz}, \mathrm{DMSO}-\mathrm{d}_{6}\right): \delta 2.39\left(\mathrm{~s}, 3 \mathrm{H}, \mathrm{CH}_{3}\right)$, $3.43\left(\mathrm{~s}, 3 \mathrm{H}, \mathrm{OCH}_{3}\right), 7.39-7.95$ (m, 19H, ArH). ESI-

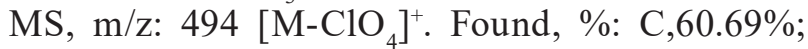
$\mathrm{H}, 4.29 \%$; N,2.30\%; P,5.18\%; S,5.43\%. Calc. for $\mathrm{C}_{30} \mathrm{H}_{25} \mathrm{ClNO}_{6} \mathrm{PS}: \mathrm{C}, 60.66 \%$; H, 4.24\%; N, 2.36\%; $\mathrm{P}$, $5.21 \%$; S, $5.40 \%$.

\section{(2-(4-Methylphenyl)-4-\{[(4-methylphenyl)} amino]carbonyl\}-1,3-thiazol-5-yl)(triphenyl)phosphonium perchlorate (compound 3). Compound 3 was synthesized following a procedure described in the literature [43]. Colorless powder, m.p. $>250{ }^{\circ} \mathrm{C}$. IR $\left(\mathrm{KBr}, v_{\max }, \mathrm{cm}^{-1}\right): 1097\left(\mathrm{ClO}_{4}\right), 1438,1534,1666$ (CO), $3314(\mathrm{NH}) .{ }^{1} \mathrm{H}$ NMR (500 MHz, DMSO$\left.\mathrm{d}_{6}\right): \delta 2.22\left(\mathrm{~s}, 3 \mathrm{H}, \mathrm{CH}_{3}\right), 2.41(\mathrm{~s}, 3 \mathrm{H}, \mathrm{CH} 3), 7.07$ (d,

Ta ble 1. The Dice Index between molecules in the test set and training set

\begin{tabular}{l|c|c|c|c|c}
\hline $\begin{array}{l}\text { Number } \\
\text { of compound }\end{array}$ & 1 & 2 & 3 & 4 & 5 \\
\hline The Dice Index & 0.62 & 0.73 & 0.70 & 0.58 & 0.58 \\
\hline
\end{tabular}


<smiles></smiles><smiles>C=CCSc1sc(-c2ccc(C)cc2)nc1[18F]</smiles><smiles>CCc1sc(-c2ccc(C)cc2)nc1[PbH2]</smiles>

Fig. 1. Chemical structure of compounds 1-5

$\left.J_{\mathrm{HH}}=7.8 \mathrm{~Hz}, 2 \mathrm{H}, \mathrm{ArH}\right), 7.27(\mathrm{~d}, \mathrm{JHH}=7.8 \mathrm{~Hz}, 2 \mathrm{H}$, ArH), 7.41 (d, $\left.J_{\mathrm{HH}}=7.8 \mathrm{~Hz}, 2 \mathrm{H}, \mathrm{ArH}\right), 7.75-7.87$ (m, $15 \mathrm{H}, \mathrm{ArH}), 8.14\left(\mathrm{~d}, J_{\mathrm{HH}}=7.8 \mathrm{~Hz}, 2 \mathrm{H}, \mathrm{ArH}\right), 10.71(\mathrm{~s}$, 1H, NH). ESI-MS, m/z: $569\left[\mathrm{M}-\mathrm{ClO}_{4}\right]^{+}$. Found, \%: C, 64.53\%; H, 4.42\%; N, $4.48 \%$; P, 4.59\%; S, 4.75\%. Calc. for $\mathrm{C}_{30} \mathrm{H}_{25} \mathrm{ClNO}_{6} \mathrm{PS}: \mathrm{C}, 64.62 \% ; \mathrm{H}, 4.52 \%$; N, $4.19 \%$; P, 4.63\%; S, 4.79\%.

[5-(Allylthio)-2-(4-methylphenyl)-1,3-thiazol4-yll(triphenyl)phosphonium iodide (compound 4). Compound $\mathbf{4}$ was synthesized following a procedure described in the literature [41]. Yellow powder, m.p. 165-167 ${ }^{\circ} \mathrm{C}$. IR (KBr, $\left.v_{\max }, \mathrm{cm}^{-1}\right): 1105,1384,1435$. ${ }^{1} \mathrm{H}$ NMR (400 MHz, DMSO-d $): \delta 2.36\left(\mathrm{~s}, 3 \mathrm{H}, \mathrm{CH}_{3}\right)$, $3.65\left(\mathrm{~d}, J_{\mathrm{HH}}=6.8 \mathrm{~Hz}, 2 \mathrm{H}, \mathrm{CH}_{2}\right), 5.20-5.31(\mathrm{~m}, 2 \mathrm{H}$, $\mathrm{CH} 2), 5.65-5.72(\mathrm{~m}, 1 \mathrm{H}, \mathrm{CH}), 7.35\left(\mathrm{~d}, J_{\mathrm{HH}}=8.0 \mathrm{~Hz}\right.$, $2 \mathrm{H}, \mathrm{ArH}), 7.74\left(\mathrm{~d}, \mathrm{~J}_{\mathrm{HH}}=8.0 \mathrm{~Hz}, 2 \mathrm{H}, \mathrm{ArH}\right), 7.84-7.97$ (m, 15H, ArH). ESI-MS, m/z: 508 [M-I] ${ }^{+}$. Found, \%: C, 58.62\%; H, 4.33\%; N, 2.19\%; P, 4.81\%; S, $10.12 \%$. Calc. for $\mathrm{C}_{31} \mathrm{H}_{27} \mathrm{INPS}_{2}$ : C,58.58 \%; H, 4.28\%; N, $2.20 \%$; P, 4.87\%; S, $10.09 \%$.

\section{[5-(Ethylthio)-2-(4-methylphenyl)-1,3-thia-} zol-4-yl](triphenyl)phosphonium iodide (compound 5). Compound 5 was synthesized following a procedure described in the literature [41]. Yellow powder, m.p. $189-190^{\circ} \mathrm{C}$. IR $\left(\mathrm{KBr}, v_{\mathrm{ma}} \mathrm{x}, \mathrm{cm}^{-1}\right)$ : 1103 , 1376, 1435. ${ }^{1} \mathrm{H}$ NMR (400 MHz, DMSO-d $\left.{ }_{6}\right): \delta 1.15$ $\left(\mathrm{t}, J_{\mathrm{HH}}=6.8 \mathrm{~Hz}, 3 \mathrm{H}, \mathrm{CH}_{3}\right), 2.36\left(\mathrm{~s}, 3 \mathrm{H}, \mathrm{CH}_{3}\right), 3.03(\mathrm{q}$, $\left.J_{\mathrm{HH}}=6.8 \mathrm{~Hz}, 2 \mathrm{H}, \mathrm{CH}_{2}\right), 7.36\left(\mathrm{~d}, J_{\mathrm{HH}}=8.0 \mathrm{~Hz}, 2 \mathrm{H}\right.$, $\mathrm{ArH}), 7.75(\mathrm{~d}, \mathrm{JHH}=8.0 \mathrm{~Hz}, 2 \mathrm{H}, \mathrm{ArH}), 7.82-7.97$ (m, 15H, ArH). ESI-MS, m/z: 496 [M-I] $]^{+}$. Found, \%: C,
$57.71 \%$; H, 4.21\%; N, $2.32 \%$; P, 4.85\%; S, $10.30 \%$. Calc. for $\mathrm{C}_{30} \mathrm{H}_{27} \mathrm{INPS}_{2}$ : C, $57.79 \% ; \mathrm{H}, 4.36 \%$; , $2.25 \%$; P, 4.97\%; S, $10.28 \%$.

Antimicrobial assay. All the compounds were screened for their antibacterial activities against Staphylococcus aureus ATCC 25923, Escherichia coli ATCC 25922, Pseudomonas aeruginosa ATCC 27853, Bacillus subtilis ATCC 6633 and fungistatic effects on Candida albicans ATCC 10231, Candida albicans strain isolated from biomaterial, Candida glabrata, Candida krusei.

Antibacterial and antifungal screening was performed by disc diffusion method in Mueller-Hinton agar and Sabouraud agar [44], respectively. The microbial load was $1 \cdot 10^{5}$ colony-forming units (CFU) in $1 \mathrm{ml}$. The tested compounds $(0.02 \mathrm{ml})$ were applied to paper disks $(6 \mathrm{~mm})$ which were placed on each agar plate. The plates were then incubated at $37{ }^{\circ} \mathrm{C}$ for $24 \mathrm{~h}$. The tests were repeated three times.

Ceftriaxone $\left(5.5 \cdot 10^{-8} \mathrm{M}\right)$ and fluconazole $\left(13 \cdot 10^{-8} \mathrm{M}\right)$ were used as positive reference standards to determine the sensitivity of the strains [45].

\section{Results and Discussion}

The QSAR study was performed using Online Chemical Modelling Environment (OCHEM) [30].

Four predictive regression models were built based on the training data set of 455 thiazole derivatives as antimicrobial inhibitors. The methods and types of descriptors by each predictive model 
are presented in Table 2. Summary statistics for all models are shown in Table 3.

The accuracy of prediction was $\mathrm{q}^{2}=0.68-0.77$, the root mean square error RMSE $=0.42-0.5$, and the mean absolute error MAE $=0.3-0.37$.

The consensus model was also used for prediction and interpretation (Table 3). Based on the results obtained for all predictive models the consensus prediction always provides the most stable decision. The consensus model between experimentally obtained data and the predicted one is shown in Fig. 2.

The model is stable and has a good forecasting ability, which can be verified using statistical parameters (high value cross-validation of parameters $\mathrm{q}^{2}$ and low MAE) [46].

The test set of 202 thiazole derivatives was analyzed using the developed QSAR models. As a result of prediction of antimicrobial activity the most potent compounds 1-5 were selected (Table 4). The samples are quaternary phosphonium salts (Fig. 1). Corresponding to the literature data, phosphonium salts are a very promising class of pharmacologically active organophosphorus compounds [47-50].

According to the provided values (Table 4), compounds $\mathbf{4}$ and $\mathbf{5}$ were predicted as the most active. The value of $\log (1 / \mathrm{MIC})$ amounted to $4.49 \pm 0.3$ and $4.51 \pm 0.23$, respectively.

The consensus prediction is very close to the mean values of prediction activity for models 1-4. Thus, the obtained results indicate that the application of consensus model provides higher prediction ability in compressing to the individual models.

In order to verify the results of the prediction, the selected compounds were screened in vitro for their antimicrobial activities against Gram-positive and Gram-negative bacteria and fungi.

The results of antimicrobial susceptibility were summarised and presented in Table 5 and 6.

\section{Ta ble 2. Molecular descriptors of QSAR models}

\begin{tabular}{|c|c|l|}
\hline Model & Method & \multicolumn{1}{|c|}{ Types of descriptors } \\
\hline 1 & kNN & Adriana.Code \\
\hline 2 & kNN & $\begin{array}{l}\text { StructuralAlerts, Chemaxon } \\
\text { Descriptors, E-State } \\
\text { indices, ALogPS }\end{array}$ \\
\hline 3 & kNN & $\begin{array}{l}\text { Chemaxon Descriptors, } \\
\text { E-State, ALogPS }\end{array}$ \\
\hline 4 & ASNN & $\begin{array}{l}\text { Chemaxon Descriptors, } \\
\text { E-State, ALogPS }\end{array}$ \\
\hline
\end{tabular}

Table 3. Statistical parameters for the predictive models

\begin{tabular}{|c|c|c|c|c|}
\hline Name & $\begin{array}{c}\text { Number } \\
\text { of descriptors }\end{array}$ & $\mathrm{q}^{2}$ & RMSE & MAE \\
\hline Model 1 & 132 & 0.73 & 0.46 & 0.33 \\
\hline Model 2 & 285 & 0.73 & 0.46 & 0.33 \\
\hline Model 3 & 157 & 0.68 & 0.50 & 0.37 \\
\hline Model 4 & 157 & 0.77 & 0.42 & 0.30 \\
\hline \multicolumn{2}{|r|}{ Consensus Model } & 0.81 & 0.39 & 0.29 \\
\hline
\end{tabular}

In general, most of the test compounds revealed better activity against Gram-positive than Gramnegative bacteria. Compounds $\mathbf{4}$ and $\mathbf{5}$ showed the highest antibacterial activity, while compounds $\mathbf{1}$, $\mathbf{2}$ and $\mathbf{3}$ showed moderate activity against all tested bacteria. $S$. aureus was the most sensitive bacterial species and $P$. aeruginosa was the most resistant species

The best antifungal activity was observed for compounds $\mathbf{4}$ and $\mathbf{5}$. It is worth noting that these compounds showed an excellent antifungal potential better than fluconazole. Considering all tested fungi, for compounds $\mathbf{4}$ and 5, C. glabrata and C. albicans (strains isolated from biomaterial) were the most sensitive, followed by C. krusei, while C. albicans ATCC 10231 was the most resistant to the tested compounds.

The structure-activity relationship analysis indicated that 1,3-thiazoles containing triphenylphosphonium group at position 4 (compounds 1, 4 and 5) are more active antimicrobial substances in comparison with 1,3-thiazoles which contain this group at position 5. In addition, antibacterial and antifungal effects of the tested compounds is increased by the introduction of sulfur substituent at the 5-position of the thiazole cycle and changes in the series: $4-\mathrm{ClC}_{6} \mathrm{H}_{4} \mathrm{~S}<\mathrm{CH}_{2}=\mathrm{CHCH}_{2} \mathrm{~S}<\mathrm{EtS}$. It should be noted that the presence of methoxycarbonyl or (4-methylphenyl)-aminocarbonyl groups (compounds 2 and 3) in 1,3-thiazol-5-yl(triphenyl) phosphonium salts significantly led to a decrease in activity of these compounds.

In conclusion, a series of new predictive QSAR models were created using data set of 455 thiazole derivatives. The high predictive quality with $\mathrm{q}^{2}$ ranged from 0.68 to 0.77 obtained suggests a good predictive ability of the developed QSAR models. Five structures of 1,3-thiazolylphosphonium salts with higher predicted antimicrobial activity were 


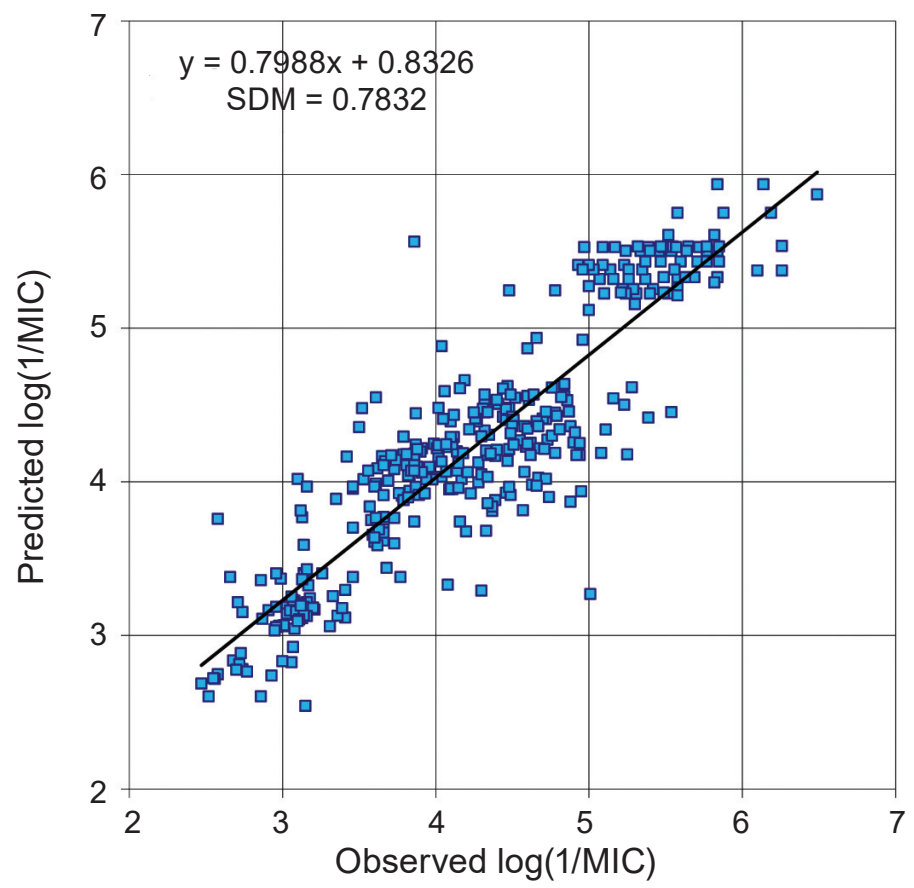

Fig. 2. Plot of experimental values versus predicted values of the consensus QSAR model

Ta ble 4. Predicted activity of compounds 1-5

\begin{tabular}{c|c|c|c|c|c|c}
\hline Compound & Model 1 & Model 2 & Model 3 & Model 4 & $\begin{array}{c}\text { Mean value } \\
\text { of } \log (1 / \mathrm{MIC})\end{array}$ & $\begin{array}{c}\text { Consensus } \\
\text { Model }\end{array}$ \\
\hline $\mathbf{1}$ & 4.08 & 4.59 & 4.08 & 4.78 & $4.38 \pm 0.31$ & 4.40 \\
$\mathbf{2}$ & 4.75 & 3.58 & 3.97 & 4.07 & $4.09 \pm 0.42$ & 4.10 \\
$\mathbf{3}$ & 4.32 & 4.18 & 4.14 & 4.55 & $4.30 \pm 0.16$ & 4.30 \\
$\mathbf{4}$ & 4.75 & 4.71 & 4.50 & 4.00 & $4.49 \pm 0.30$ & 4.50 \\
$\mathbf{5}$ & 4.75 & 4.71 & 4.31 & 4.25 & $4.51 \pm 0.23$ & 4.50 \\
\hline
\end{tabular}

Table 5. Antibacterial activity of compounds 1-5

\begin{tabular}{c|c|c|c|c}
\hline \multirow{2}{*}{ Compound } & \multicolumn{4}{|c}{ Diameter of the inhibitory zone, mm } \\
\cline { 2 - 5 } & \multicolumn{2}{|c}{ Gram-positive } & \multicolumn{2}{c}{ Gram-negative } \\
\cline { 2 - 5 } & $\begin{array}{c}\text { Staphylococcus } \\
\text { aureus ATCC 25923 }\end{array}$ & $\begin{array}{c}\text { Bacillus subtilis } \\
\text { ATCC 6633 }\end{array}$ & $\begin{array}{c}\text { Escherichia coli } \\
\text { ATCC 25922 }\end{array}$ & $\begin{array}{c}\text { Pseudomonas } \\
\text { aeruginosa } \\
\text { ATCC 27853 }\end{array}$ \\
\hline $\mathbf{1}$ & $13.6 \pm 0.3$ & $11.3 \pm 0.6$ & $10.3 \pm 0,3$ & na \\
$\mathbf{2}$ & na & $11.0 \pm 0.6$ & $10.4 \pm 0.3$ & na \\
$\mathbf{3}$ & $20.0 \pm 0.6$ & $11.6 \pm 0.6$ & $13.8 \pm 0.6$ & na \\
$\mathbf{4}$ & $24.3 \pm 0.3$ & $22.6 \pm 0.3$ & $17.3 \pm 0.3$ & $12.5 \pm 0.3$ \\
$\mathbf{5}$ & $25.3 \pm 0.3$ & $23.3 \pm 0.3$ & $16.0 \pm 0.6$ & $15.6 \pm 0.3$ \\
Ceftriaxone & $28.3 \pm 0.9$ & $34.4 \pm 0.3$ & $28.3 \pm 0.6$ & $20.1 \pm 0.3$ \\
\hline
\end{tabular}

Note. na - no activity. The content of the test compounds $1-5$ and ceftriaxone on a disk were $5.5 \cdot 10^{-8} \mathrm{M}$. 
Ta ble 6. Antifungal activity of compounds 1-5

\begin{tabular}{c|c|c|c|c}
\hline \multirow{2}{*}{ Compound } & \multicolumn{4}{|c}{ Diameter of the inhibitory zone, mm } \\
\cline { 2 - 5 } & $\begin{array}{c}\text { Candida albicans } \\
\text { ATCC 10231 }\end{array}$ & $\begin{array}{c}\text { Candida albicans strain } \\
\text { isolated from biomaterial }\end{array}$ & Candida glabrata & Candida krusei \\
\hline $\mathbf{1}$ & $13.4 \pm 0.3$ & $20.3 \pm 0.3$ & $19.1 \pm 0.3$ & $13.9 \pm 0.3$ \\
$\mathbf{2}$ & na & $16.6 \pm 0.3$ & na & $10.2 \pm 0.3$ \\
$\mathbf{3}$ & $16.3 \pm 0.3$ & $23.3 \pm 0.3$ & $11.0 \pm 0.3$ & na \\
$\mathbf{4}$ & $18.9 \pm 0.3$ & $32.0 \pm 0.6$ & $35.3 \pm 0.3$ & $24.8 \pm 0.3$ \\
$\mathbf{5}$ & $18.2 \pm 0.3$ & $32.3 \pm 0.3$ & $37.4 \pm 0.6$ & $30.5 \pm 0.6$ \\
Fluconazole & $17.3 \pm 0.3$ & $19.6 \pm 0.3$ & na & $13.0 \pm 0.6$ \\
\hline
\end{tabular}

Note. na - no activity. The content of the test compounds $\mathbf{1 - 5}$ and fluconazole on a disk were $13 \cdot 10^{-8} \mathrm{M}$.

synthesized and tested in vitro. The results showed that all the compounds exhibited good antimicrobial activities. Given the importance of the standard deviation in case of the predicted activities for compounds $\mathbf{1}$ and $\mathbf{3}$ the experimental results are in a good agreement with data obtained using regression QSAR models.

Thus, the developed QSAR models can be an efficient tool for the selection of new antimicrobial active thiazole derivatives as well as for the designing and forecasting of new potentially active compounds with suitable biological properties. Moreover, novel 1,3-thiazol-4-ylphosphonium salts 4 and 5 could be considered as a promising candidate with antimicrobial activity for further investigation.

\section{QSAR ДОСЛІДЖЕННЯ TA} АНТИМІКРОБНИЙ ПОТЕНЦАЛ 1,3-ТІАЗОЛІЛФОСФОНІЕВИХ СОЛЕЙ

\author{
М. М. Труші ${ }^{l *}$, В. В. Ковалішин ${ }^{l}$, \\ В. М. Благодатний ${ }^{2}$, В. С. Бровареиьь ${ }^{l}$ \\ С. Г. Пільо ${ }^{\prime}$ В. М. Прокопенко ${ }^{\text {, }}$ \\ Д. М. Година', Л. О. Метелиия
}

${ }^{1}$ Інститут біоорганічної хімії та нафтохімії НАН України, Київ;

${ }^{2}$ Національна медична академія післядипломної освіти імені П. Л. Шупика, Київ, Україна;

*e-mail:maria@bpci.kiev.ua

Побудовано регресійні QSAR-моделі для прогнозу антимікробної активності нових похідних тіазолу. Сполуки з високою прогнозованою активністю були синтезовані та тестовані проти грибів та грампозитивних і грамнегативних бактерій. 1,3-тіазол-4-ілфосфонієві солі 4 та 5 виявили значну антибактеріальну та високу протигрибкову активність. Результати прогнозу корелюють 3 результатами експериментальних досліджень, що свідчить про високу прогнозуючу здатність створених QSAR моделей.

К л юч о в с ло в а: QSAR, тіазолілфосфонієві солі, антимікробна активність.

\section{QSAR ИССЛЕДОВАНИЯ И АНТИМИКРОБНЫЙ ПОТЕНЦИАЛ 1,3-ТИАЗОЛИЛФОСФОНИЕВЫХ СОЛЕЙ}

\author{
М. Н. Труші ${ }^{l *}$ В. В. Ковалишин ${ }^{l}$, \\ В. Н. Благодатный, В. С. Броварец ${ }^{l}$, \\ С. Г. Пильо , В. Н. Прокопенко, \\ Д. Н. Година , Л. А. Метелииа ${ }^{1}$
}

\author{
${ }^{1}$ Институт биоорганической химии \\ и нефтехимии НАН Украины, Киев; \\ ${ }^{2}$ Национальная медицинская академия \\ последипломного образования имени \\ П. Л. Шупика, Киев, Украина; \\ *e-mail:maria@bpci.kiev.ua
}

В данной работе представлены регрессионные QSAR-модели для прогноза антимикробной активности новых производных тиазола. Соединения с высшей прогнозируемой способностью были синтезированы и тестированы против грибов, грамположительных и грамотрицательных бактерий. 1,3-тиазол-4-илфосфониевые соли 4 и 5 показали значительные антибактериальные свойства и высокую противогрибковую активность. Результаты прогноза коррелируют с результатами экспериментальных исследований, что свидетельствует о хорошей прогнозирующей способности созданных QSAR моделей. 
К л ю че вы е с ло в a: QSAR, тиазолилфосфониевые соли, антибактериальная активность.

\section{References}

1. Hargrave KD, Hess FK, Oliver JT. N-(4substituted-thiazolyl)oxamic acid derivatives, a new series of potent, orally active antiallergy agents. J Med Chem. 1983; 26(8): 1158-1163.

2. Musser JH, Brown RE, Loev B, Bailey K, Jones H, Kahen R, Huang FC, Khandwala A, Leibowitz M, Sonnino-Goldman P. Synthesis of 2-(2,3-dihydro-2-oxo-1,3,4-oxadiazol-5-yl) benzo heterocycles. A novel series of orally active antiallergic agents. J Med Chem. 1984; 27(2): 121-125.

3. Patt WC, Hamilton HW, Taylor MD, Ryan MJ, Taylor DG Jr, Connolly CJ, Doherty AM, Klutchko SR, Sircar I, Steinbaugh BA, et al. Structure-activity relationships of a series of 2-amino-4-thiazole-containing renin inhibitors. J Med Chem. 1992; 35(14): 2562-2572.

4. Sharma RN, Xavier FP, Vasu KK, Chaturvedi SC, Pancholi SS. Synthesis of 4-benzyl1,3-thiazole derivatives as potential antiinflammatory agents: an analogue-based drug design approach. J Enzyme Inhib Med Chem. 2009;24(3): 890-897.

5. Shelke SH, Mhaske PC, Nandave M, Narkhade S, Walhekar NM, Bobade VD. Synthesis and pharmacological evaluation of a novel series of 3-aryl-2-(2-substituted-4-methylthiazole-5-yl) thiazolidin-4-one as possible anti-inflammatory and antimicrobial agents. Bioorg Med Chem Lett. 2012; 22(20): 6373-6376.

6. Jaen JC, Wise LD, Caprathe BW, Tecle H, Bergmeier S, Humblet CC, Heffner TG, Meltzer LT, Pugsley TA. 4-(1,2,5,6-Tetrahydro1-alkyl-3-pyridinyl)-2-thiazolamines: a novel class of compounds with central dopamine agonist properties. J Med Chem. 1990; 33(1): 311-317.

7. Ergenç N, Capan G, Günay NS, Ozkirimli S, Güngör M, Ozbey S, Kendi E. Synthesis and hypnotic activity of new 4-thiazolidinone and 2-thioxo-4,5-imidazolidinedione derivatives. Arch Pharm (Weinheim). 1999; 332(10): 343-347.

8. Carter JS, Kramer S, Talley JJ, Penning T, Collins P, Graneto MJ, Seibert K, Koboldt CM, Masferrer J, Zweifel B. Synthesis and activity of sulfonamide-substituted 4,5-diaryl thiazoles as selective cyclooxygenase-2 inhibitors. Bioorg Med Chem Lett. 1999; 9(8): 1171-1174.

9. Sondhi SM, Singh N, Lahoti AM, Bajaj K, Kumar A, Lozach O, Meijer L. Synthesis of acridinyl-thiazolino derivatives and their evaluation for anti-inflammatory, analgesic and kinase inhibition activities. Bioorg Med Chem. 2005; 13(13): 4291-4299.

10. Kalkhambkar RG, Kulkarni GM, Shivkumar H, Rao RN. Synthesis of novel triheterocyclic thiazoles as anti-inflammatory and analgesic agents. Eur J Med Chem. 2007; 42(10): 12721276.

11. Bell FW, Cantrell AS, Högberg M, Jaskunas SR, Johansson NG, Jordan CL, Kinnick MD, Lind P, Morin JM Jr, Noréen R. Phenethylthiazolethiourea (PETT) compounds, a new class of HIV-1 reverse transcriptase inhibitors. 1. Synthesis and basic structureactivity relationship studies of PETT analogs. J Med Chem. 1995; 38(25): 4929-4936.

12. Rawal RK, Tripathi R, Katti SB, Pannecouque $\mathrm{C}$, De Clercq E. Design and synthesis of 2-(2,6-dibromophenyl)-3-heteroaryl-1,3-thiazolidin-4-ones as anti-HIV agents. Eur J Med Chem. 2008; 43(12): 2800-2806.

13. Turan-Zitouni G, Özdemir A, Kaplancikli ZA. Synthesis and Antiviral Activity of Some (3,4-Diaryl-3H-thiazol-2-ylidene)pyrimidin-2-yl Amine Derivatives. Phosphorus Sulfur Silicon Relat Elem. 2011; 186(2): 233-239.

14. Kumar D, Sundaree S, Johnson EO, Shah K. An efficient synthesis and biological study of novel indolyl-1,3,4-oxadiazoles as potent anticancer agents. Bioorg Med Chem Lett. 2009; 19(15): 4492-4494.

15. Gürsoy E, Güzeldemirci NU. Synthesis and primary cytotoxicity evaluation of new imidazo[2,1-b]thiazole derivatives. Eur J Med Chem. 2007; 42(3): 320-326.

16. Shao L, Zhou X, Hu Y, Jin Z, Liu J, Fang J. Synthesis and evaluation of novel ferrocenyl thiazole derivatives as anticancer agents. Synthes React Inorg Metal-Org Nano-Metal Chem. 2006; 36(4): 325-330.

17. Abbs T.F., Reji F., Devi S. K. C., Thomas K. K., Sreejalekshmi K. G., Manju S. L., Francis M., Philip S.K., Bharathan A., Rajasekharan K. N. Synthesis and cytotoxicity studies of thiazole analogs of the anticancer marine alkaloid dendrodoine. Indian J. Chem. 2008; 47B: 11451150 . 
18. Hutchinson I, Bradshaw TD, Matthews CS, Stevens MF, Westwell AD. Antitumour benzothiazoles. Part 20: 3'-cyano and 3'-alkynylsubstituted 2-(4'-aminophenyl)benzothiazoles as new potent and selective analogues. Bioorg Med Chem Lett. 2003; 13(3): 471-474.

19. Luzina EL, Popov AV. Synthesis and anticancer activity of N-bis(trifluoromethyl)alkyl-N'thiazolyl and N-bis(trifluoromethyl)alkyl-N'benzothiazolyl ureas. Eur J Med Chem. 2009; 44(12): 4944-4953.

20. Bondock S, Fadaly W, Metwally MA. Synthesis and antimicrobial activity of some new thiazole, thiophene and pyrazole derivatives containing benzothiazole moiety. Eur J Med Chem. 2010; 45(9): 3692-3701.

21. Desai NC, Bhatt N, Somani H, Trivedi A. Synthesis, antimicrobial and cytotoxic activities of some novel thiazole clubbed 1,3,4-oxadiazoles. Eur J Med Chem. 2013; 67: 54-59.

22. Karegoudar P, Karthikeyan MS, Prasad DJ, Mahalinga M, Holla BS, Kumari NS. Synthesis of some novel 2,4-disubstituted thiazoles as possible antimicrobial agents. Eur J Med Chem. 2008; 43(2): 261-267.

23. Karki R, Rao GK, Gupta A, Mariappan G, Adhikari S. Synthesis, Characterization and Antimicrobial Activities of Schiff bases of 2-amino-4-(O-chloroanilino)-1, 3-thiazole. J App Pharm Sci. 2013; 3(07): 93-96.

24. Chimenti F, Bizzarri B, Bolasco A, Secci D, Chimenti P, Granese A, Carradori S, D'Ascenzio M, Lilli D, Rivanera D. Synthesis and biological evaluation of novel 2,4-disubstituted1,3-thiazoles as anti-Candida spp. agents. Eur $J$ Med Chem. 2011; 46(1): 378-382.

25. Sarojini BK, Krishna BG, Darshanraj CG, Bharath BR, Manjunatha H. Synthesis, characterization, in vitro and molecular docking studies of new 2,5-dichloro thienyl substituted thiazole derivatives for antimicrobial properties. Eur J Med Chem. 2010; 45(8): 3490-3496.

26. Siddiqui N, Arshad MF, Ahsan W, Alam MS. Thiazoles: a valuable insight into the recent advances and biological activities. Int $J$ Pharmaceut Sci Drug Res. 2009; 1(3): 136-143.

27. ChEMBL. Available at https://www.ebi.ac.uk/ chembl/.

28. Granito CE, Rosenberg MD. Chemical Substructure Index (CSI) - a new research tool. J Chem Doc. 1971; 11(4): 251-256.
29. ChemAxon Products. Available at http://www. chemaxon.com/products/.

30. OCHEM. Available at https://ochem.eu.

31. Sushko I, Novotarskyi S, Körner R, Pandey AK, Rupp M, Teetz W, Brandmaier S, Abdelaziz A, Prokopenko VV, Tanchuk VY, Todeschini R, Varnek A, Marcou G, Ertl P, Potemkin V, Grishina M, Gasteiger J, Schwab C, Baskin II, Palyulin VA, Radchenko EV, Welsh WJ, Kholodovych V, Chekmarev D, Cherkasov A, Aires-de-Sousa J, Zhang QY, Bender A, Nigsch F, Patiny L, Williams A, Tkachenko V, Tetko IV. Online chemical modeling environment (OCHEM): web platform for data storage, model development and publishing of chemical information. $J$ Comput Aided Mol Des. 2011; 25(6): 533-554.

32. Tetko IV. Associative neural network. Methods Mol Biol. 2008; 458: 185-202.

33. Adriana.CODE. Available at http://docs.ochem. eu/display/MAN/Adriana.CODE.

34. Tetko IV, Tanchuk VY. Application of associative neural networks for prediction of lipophilicity in ALOGPS 2.1 program. $J$ Chem Inf Comput Sci. 2002; 42(5): 1136-1145.

35. Kier LB, Hall LH. An electrotopological-state index for atoms in molecules. Pharm Res. 1990; 7(8): 801-807.

36. Sushko I, Salmina E, Potemkin VA, Poda G, Tetko IV. ToxAlerts: a Web server of structural alerts for toxic chemicals and compounds with potential adverse reactions. $J$ Chem Inf Model. 2012; 52(8): 2310-2316.

37. Nantasenamat $C$, Isarankura-Na-Ayudhya $C$, Naenna T, Prachayasittikul V. A practical overview of quantitative structure-activity relationship. EXCLI J. 2009; 8: 74-88.

38. Mahobia NK, Patel RD, Sheikh NW, Singh SK, Mishra A, Dhardubey R. Validation method used in quantitative structure activity relationship. Der Pharma Chemica. 2010; 2: 260-271.

39. Sushko I, Novotarskyi S, Körner R, Pandey AK, Cherkasov A, Li J, Gramatica P, Hansen K, Schroeter T, Müller KR, Xi L, Liu H, Yao X, Öberg T, Hormozdiari F, Dao P, Sahinalp C, Todeschini R, Polishchuk P, Artemenko A, Kuz'min V, Martin TM, Young DM, Fourches D, Muratov E, Tropsha A, Baskin I, Horvath D, Marcou G, Muller C, Varnek A, Prokopenko VV, Tetko IV. Applicability domains for classification problems: Benchmarking of distance to models 
for Ames mutagenicity set. $J$ Chem Inf Model. 2010; 50(12): 2094-2111.

40. Sushko I, Novotarskyi S, Korner R, Pandey AK, Kovalishyn VV, Prokopenko VV, Tetko IV. Applicability domain for in silico models to achieve accuracy of experimental measurements. J Chemometrics. 2010; 24(3-4): 202-208.

41. Lobanov OP, Martynyuk AP, Drach BS. Reactions of (2,2-dichloro-1-acylaminovinil) triphenylphosphonium chloride with nucleophiles. Zhurn Obsh Khim. 1980; 50(10): 22482257. (In Russian).

42. Brovarets VS, Zyuz KV, Vydzhak RN, Vinogradova TK, Drach BS. Synthesis of 2-acylaminovinylphosphonium salts, their analogues and derivatives based on the chlorinecontaining unsaturated azlactones. Rus J Gen Chem. 1994; 64: 1462-1470. (In Russian).

43. Brovarets VS, Zyuz KV, Romanenko EA, Drach BS. Transformations of the reaction product of 4-dichloromethylene-2-phenyl$5(4 \mathrm{H})$-oxazolone with triphenylphosphine to novel derivatives of triazoles and selenazoles. Zhurn Obsh Khim. 1995; 65(12): 1972-1978. (In Russian).

44. Bauer AW, Kirby WM, Sherris JC, Turck M. Antibiotic susceptibility testing by a standardized single disk method. Am J Clin Pathol. 1966; 45(4): 493-496.

45. CLSI. Performance Standards for Antimicrobial Susceptibility Testing; Twenty-First Informational Supplement. CLSI document M100-S21. Wayne, PA: Clinical and Laboratory Standards Institute; 2011.
46. Tropsha A, Gramatica P, Gombar VK. The importance of being earnest: validation is the absolute essential for successful application and interpretation of QSPR models. QSAR Comb. Sci. 2003; 22(1): 69-77.

47. Millard M, Pathania D, Shabaik Y, Taheri L, Deng J, Neamati N. Preclinical evaluation of novel triphenylphosphonium salts with broadspectrum activity. PLoS One. 2010; 5(10); e13131.

48. Dunn EA, Roxburgh M, Larsen L, Smith RA, McLellan AD, Heikal A, Murphy MP, Cook GM. Incorporation of triphenylphosphonium functionality improves the inhibitory properties of phenothiazine derivatives in Mycobacterium tuberculosis. Bioorg Med Chem. 2014; 22(19): 5320-5328.

49. Gorbunova M. Novel guanidinium and phosphonium polysulfones: synthesis and antimicrobial activity. J Chem Pharm Res. 2013; 5: 185-192.

50. Pugachev MV, Shtyrlin NV, Sysoeva LP, Nikitina EV, Abdullin TI, Iksanova AG, Ilaeva AA, Musin RZ, Berdnikov EA, Shtyrlin YG. Synthesis and antibacterial activity of novel phosphonium salts on the basis of pyridoxine. Bioorg Med Chem. 2013; 21(14): 4388-4395. 